\title{
WHERE ARE THE LIGHTNING HOTSPOTS ON EARTH?
}

\author{
by Rachel I. Albrecht, Steven J. Goodman, Dennis E. Buechler, \\ Richard J. Blakeslee, and Hugh J. Christian
}

\begin{abstract}
Earth's lightning hotspots are revealed with very high-resolution lightning climatology derived from 16 years of space-based Lightning Imaging Sensor observations.
\end{abstract}

AfFILIATIONS: AlbReCHT-Instituto de Astronomia, Geofísica e Ciências Atmosféricas, Universidade de São Paulo, São Paulo, Brazil, and Cooperative Institute for Climate and SatellitesMaryland, University of Maryland, College Park, College Park, Maryland; Goodman - NOAA/National Environmental Satellite Data and Information Service, Greenbelt, Maryland; BUECHLER AND CHRISTIAN-University of Alabama in Huntsville, Huntsville, Alabama; BLAKESLEE-Marshall Space Flight Center, National Aeronautics and Space Administration, Huntsville, Alabama CORRESPONDING AUTHOR: Rachel Ifanger Albrecht, Universidade de São Paulo, Rua do Matão, 1226, 05508-090 São Paulo-SP, Brazil

E-mail: rachel.albrecht@iag.usp.br

The abstract for this article can be found in this issue, following the table of contents.

DOI:I0.II75/BAMS-D-I4-00193.I

A supplement to this article is available online (I0.I175/BAMS-D-14-00193.2)

In final form 2 February 2016

(C)2016 American Meteorological Society orbiting instruments were used by several authors to estimate global flash rates [World Meteorological Organization (WMO) 1953; Kotaki 1984; Orville and Henderson 1986; Goodman and Christian 1993; Williams and Heckman 1993; Heckman et al. 1998; Mackerras et al. 1998; Boccippio et al. 2000; Williams et al. 2000; Christian et al. 2003; Albrecht et al. 2014]. Ground-based radio frequency measurement systems provide reliable lightning location but offer limited spatial coverage, especially over the oceans and the tropics. These systems detect predominantly cloudto-ground lightning relying on land-based receivers that are at great distances from where lightning is striking. It was not until the satellite era that consistent monitoring of total lightning (i.e., cloud to ground and intracloud) was possible at the planetary scale. The first lightning observations from space are dated from the early 1960s using both optical and radio frequency sensors. More than a dozen spacecraft orbiting Earth have flown instruments that recorded signals from thunderstorm lightning over the past 45 years. These instruments generally had low spatial resolution and low detection efficiency and were unable to provide precise measurements of lightning characteristics (Christian et al. 1992; Goodman and Christian 1993).

In 1995, the National Aeronautics and Space Administration (NASA) launched the Optical Transient Detector (OTD) - a prototype of the Lightning Imaging Sensor (LIS) instrument-as a hosted payload on board the Microlab-1 (later renamed 
as OrbView-1) small communications satellite. The OTD was the first instrument specifically designed to detect lightning from space during both day and night with storm-scale resolution (Christian et al. 2003). In a low-Earth-orbit inclination of $70^{\circ}$ and at $740 \mathrm{~km}$ of altitude, OTD observed individual storms in a region $1,300 \mathrm{~km} \times 1,300 \mathrm{~km}$ for about 3 min during each satellite overpass between 1995 and 2000. The result is an annual global flash rate estimate of $44 \mathrm{fl} \mathrm{s}^{-1}$ with a maximum of $55 \mathrm{fl} \mathrm{s}^{-1}$ in the boreal summer and a minimum of $35 \mathrm{fl} \mathrm{s}^{-1}$ in the austral summer (Christian et al. 2003). The LIS on board the NASA Tropical Rainfall Measuring Mission (TRMM) was launched in November 1997 into a precessing orbit inclination of $35^{\circ}$ at an altitude of $350 \mathrm{~km} .{ }^{1}$ From this orbit an individual storm within the LIS field of view of $600 \mathrm{~km} \times 600 \mathrm{~km}$ was observable for about $90 \mathrm{~s}$, with no discernible degradation during its time in orbit (Buechler et al. 2014). The LIS was powered off and the TRMM mission ended data collection on 8 April 2015, thus extending what was originally a 3 -yr mission for a total of $17+$ years.

The overall measurement objective of LIS was to supply further insights into the nature of tropical oceanic and continental convective clouds, providing the basis for the development of a comprehensive global thunderstorm and lightning climatology. With this focus, total lightning observed from OTD and LIS have been used to analyze global and regional thunderstorm electrical activity (e.g., Boccippio et al. 2000; Goodman et al. 2000; Williams et al. 2000; Christian et al. 2003; Cecil et al. 2005; Petersen et al. 2005; Zipser et al. 2006; Liu et al. 2011; Cecil et al. 2014). Based on 5 years of OTD and 3 years of LIS measurements, Christian et al. (2003) and Boccippio et al. (2000) presented the first detailed lightning climatology maps, which described the frequency and distribution of lightning over the globe and the tropics, respectively. These authors were pioneers in constructing comprehensive total lightning climatologies using a $0.5^{\circ}$ resolution for annualized composite and $2.5^{\circ}$ resolution for decomposition of the annual cycle. To overcome limited sampling in places with low flash rates such as oceans, arid regions, and higher latitudes sampled only by OTD, these climatology maps have substantial spatial and temporal smoothing as well as low-pass digital filtering. Christian et al. (2003) and Boccippio et al. (2000) found that the greatest flash rates occur indeed in the tropical region along coastal areas,

${ }^{1}$ TRMM was boosted to $402 \mathrm{~km}$ of altitude in August 2001 to extend the mission lifetime. mountainous regions, regions with frequent extratropical synoptic-scale cyclones, and large-scale convergence zones [South Atlantic, South Pacific, and intertropical convergence zone (ITCZ)]. Based on the smoothed $0.5^{\circ}$-resolution total lightning map from OTD, Christian et al. (2003) declared the equatorial Congo basin as the lightning hotspot of the planet, more specifically at Kamembe, Rwanda, in the top place, and several locations in the Democratic Republic of the Congo as well as Nigeria, Gabon, Madagascar, and Cameroon. In South America, the principal lightning hotspots were located in northern Argentina extending toward Paraguay and Brazil, along one of the regions of the most intense thunderstorms on Earth (Cecil et al. 2005; Zipser et al. 2006), and a few isolated locations in Colombia, Brazil, and Peru. In Asia, Kuala Lumpur, Malaysia, stood out as the place with the most lightning occurrence; in Australia, Fitzroy Crossing stood out, and in North America, Tampa, Florida stood out. Boccippio et al. (2000) also revealed the Congo basin as the region with the highest flash rate per thunderstorm cell.

A merged global lightning $0.5^{\circ}$-resolution dataset composed of individual LIS and OTD orbits has been updated each year and is freely available online (http://lightning.nsstc.nasa.gov/data/data_lis-otd -climatology.html; Cecil et al. 2014). This LIS-OTD climatology is the most accurate depiction of total lightning across the planet to date, named the High Resolution Annual Climatology (HRAC) database. Following the methodology of Christian et al. (2003) and Boccippio et al. (2000), the HRAC also has spatial (2.5 $5^{\circ}$ moving average) and temporal ( 55 days moving average) smoothing and low-pass digital filtering. Cecil et al. (2014) reconfirm the earlier lightning flash rate climatology, with a mean global flash rate of $46 \mathrm{fl} \mathrm{s}^{-1}$ (varying from around $35 \mathrm{fl} \mathrm{s}^{-1}$ in austral summer to $60 \mathrm{fl} \mathrm{s}^{-1}$ in boreal summer) with a peak annual flash rate of $160 \mathrm{fl} \mathrm{km}^{-2} \mathrm{yr}^{-1}$ over the eastern Congo basin.

In this paper, we depict a very high-resolution total lightning climatology gridded at $0.1^{\circ}$ using 16 years (1998-2013) of observations from LIS. We used individual LIS orbit data files available from the NASA Earth Observing System Data and Information System (EOSDIS) Global Hydrology Resource Center (GHRC; http://ghrc.nsstc.nasa.gov/). TRMM started its descending path to decommissioning in 2014 with several instrument outages during the period, which we expect could introduce uncertainties on the climatology, ranking, and annual and diurnal cycles presented in this study. Therefore, 2014 and 2015 data were not included in this study. The focus 
of this paper is to identify Earth's lightning hotspots and other regional features revealed by a detailed very high-resolution satellite-derived climatology. The targets of our analysis are the places where most lightning occurs, that is, the lightning hotspots on Earth. Therefore, no temporal or spatial smoothing is applied to the lightning climatology to best reveal the specific location of lightning hotspots tied to orographic features. The methodology to derive the climatology in this study is similar to that used in the previous satellite depictions (Christian et al. 2003; Cecil et al. 2014) but at higher resolution and no spatial smoothing to the full climatology dataset (besides the intrinsic smoothing of gridding data). This climatology is called the LIS very high-resolution climatology and is composed of five datasets (http:// dx.doi.org/I0.5067/LIS/LIS/DATA306): very highresolution full climatology (VHRFC), very highresolution diurnal climatology (VHRDC), very high-resolution monthly climatology (VHRMC), very high-resolution seasonal climatology (VHRSC), and very high-resolution annual cycle (VHRAC). Each dataset has the flash rate density (FRD) and viewtime (VT) gridded fields, all compiled with LIS data from 1998 to 2013. A full description of these fields and the details on the computation of this $0.1^{\circ}$-resolution climatology, as well as its uncertainties, can be found in the online supplemental material (OSM; see online at http://dx.doi.org/I0.II75 /BAMS-D-I4-00193.2) accompanying this article. It is imperative that potential users of this dataset read the OSM to better understand the insights of the total climatology computations. The datasets and figure maps from this manuscript are publicly available and hosted by the GHRC online (at https://ghrc.nsstc .nasa.gov/pub/lis/climatology/LIS/). The reader can view detailed close-ups of the features described in the next sections using Google Earth API at http://lightning.nsstc.nasa.gov/data/data_lis-vhr -climatology.html.

TRMM LIS VERY HIGH-RESOLUTION FULL CLIMATOLOGY. The TRMM LIS total lightning FRD (fl km-2 $\mathrm{yr}^{-1}$ ) climatology map from 16 years (1998-2013) of observations, and in very high horizontal $\left(0.1^{\circ}\right)$ resolution, is shown in Fig. 1. Figure 1 also shows the local time of maximum FRD and the month of maximum FRD, based on the VHRDC and VHMC datasets, respectively. As expected, the largescale features of tropical thunderstorm activity found by Boccippio et al. (2000), Christian et al. (2003), and Cecil et al. (2014) are still captured here at $0.1^{\circ}$ resolution. The difference between land and ocean can be clearly observed by intense convection occurring more frequently over the continents than the oceans, mainly due to the lower heat capacity of land, where the ground can warm the air more effectively, increasing convective updrafts (Williams and Stanfill 2002; Williams 2004; Futyan and Del Genio 2007). In general, the local standard time (LST) and month of maximum lightning activity (Figs. $1 \mathrm{~b}$ and 1c, respectively) over land occur during the afternoon (1200 to 1800 LST) and the hemisphere summer trimester (December-February in the Southern Hemisphere and June-August in Northern Hemisphere). However, some coastal-oceanic regions present moderate FRD (up to $30 \mathrm{fl} \mathrm{km}^{-2} \mathrm{yr}^{-1}$ ) associated with frequent synoptic-scale extratropical cyclones and cold fronts (such as south-southeast coasts of Brazil, South Africa, and Australia) that occur throughout the year and at all times of the day (i.e., there is a negligible or nonexistent annual and diurnal cycle). Moderate lightning activity is also observed within the Gulf of Mexico (with a peak in winter/spring) and over the warm Gulf Stream at the Southeastern U.S. coast (summertime peak). During the winter months, the Gulf of Mexico region has twice the number of lightning flashes, days, and hours during El Niño years than non-El Niño years (Goodman et al. 2000).

Monsoonal regions such as the Amazon and Indian subcontinent have the most lightning activity during spring, considered the premonsoon phase (Williams et al. 2002; Kandalgaonkar 2003; Kodama et al. 2005; Petersen et al. 2006; Lal and Pawar 2009; Albrecht et al. 2011b). The Indian subcontinent as a whole has a lightning maximum during the premonsoon season and a secondary peak in late August to October (Kandalgaonkar 2005; Lal and Pawar 2009). This second peak is related to thunderstorms during the postmonsoon season in the central region (also shown in Fig. 1c).

Regions where thunderstorm activity is dominated by land-sea breeze interactions show high lightning activity (30-50 $\mathrm{fl} \mathrm{km}^{-2} \mathrm{yr}^{-1}$ ) over land near the coast (Fig. 1a), where the maximum thunderstorm activity occurs during afternoon (1300-1700 LST; Fig. 1b) and during the summer (Fig. 1c). At night, offshore wind flow develops thunderstorms over the oceans near coastal regions with low $\left(6-10 \mathrm{fl} \mathrm{km}^{-2} \mathrm{yr}^{-1}\right)$ to moderate (10-30 $\mathrm{fl} \mathrm{km}^{-2} \mathrm{yr}^{-1}$ ) lightning activity. Several pronounced examples of this are found in the coastal regions of the continents and islands in Central America and the Maritime Continent. One noticeable example is the Strait of Malacca, a narrow stretch of water between peninsular Malaysia and Sumatra Island (Indonesia). During the day, onshore breezes foment convergence and thunderstorm 


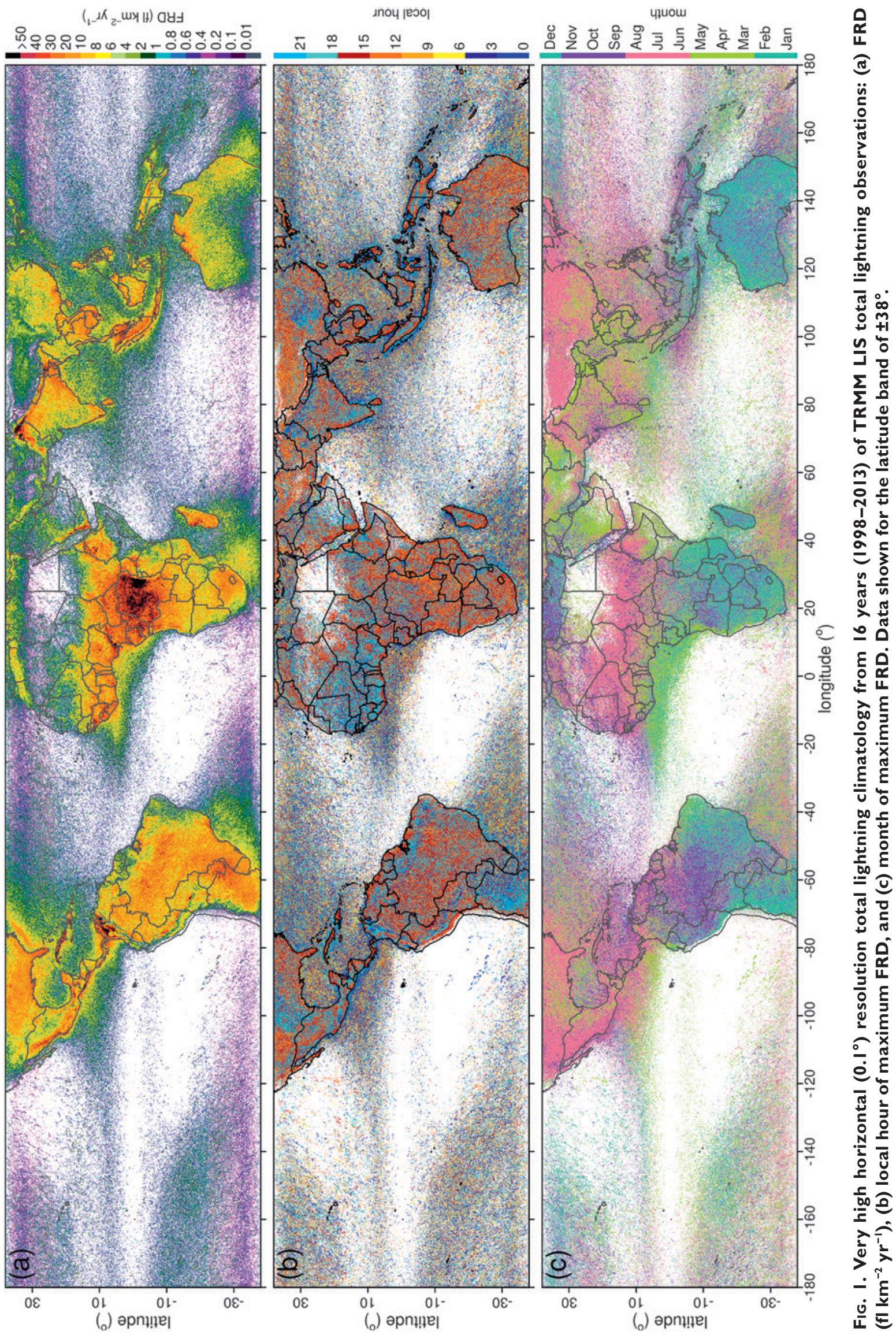


development over the island, while during the night, the offshore breeze blows from both landmasses toward the Strait of Malacca, converging over warm seawater and driving nocturnal thunderstorms (more details in the next section). The presence of enhanced nocturnal ice scattering from clouds at the Strait of Malacca has been reported by Nesbitt and Zipser (2003), and Virts et al. (2013) reports high cloudto-ground lightning activity during the night in this same region. Nocturnal lightning is also observed at regions with complex terrain, such as in the Andes (especially in Colombia) and the Himalayas (Virts et al. 2013). Moreover, nocturnal and early morning moderate-to-high lightning activity is found in the central-southern U.S. Great Plains, northern Argentina, Southeast Asia, and West Africa. These regions produce large mesoscale convective systems (MCS) predominantly during spring time (Fig. 1c) with maximum convective activity during the night (Fig. 1b) (Laing and Fritsch 1997; Kodama et al. 2005; Rasmussen and Houze 2011; Rasmussen et al. 2014).

Places with very high FRD (higher than $50 \mathrm{fl} \mathrm{km}{ }^{-2} \mathrm{yr}^{-1}$ ) are extensively located over the Congo basin; the coastal zones of Cuba, Saudi Arabia, and Yemen; and near several mountain regions, such as the Andes, Sierra Madre Mountains (at the west coast from northern Mexico to Guatemala), western highlands of the Cameroon line, Mitumba Mountains, Himalayas, and mountain ranges in Indonesia and Papua New Guinea. It is over these complex terrain regions that most of Earth's lightning hotspots are located. These hotspots are ranked and identified in the following section.

\section{LIGHTNING FLASH RATE DENSITY RANKING AND CONTINENTAL LANDMASSES' HOTSPOTS. The individual} $0.1^{\circ}$ total lightning flash rate density grid boxes from Fig. 1 were ranked from highest to lowest values and associated with a populated place name with more than 1,000 inhabitants from the geographical database GeoNames (www.geonames.org/). To minimize an excessive number of identical place names within clusters of very high flash rate density $\left(>50 \mathrm{fl} \mathrm{km}^{-2} \mathrm{yr}^{-1}\right)$, such as Africa and the northern region of South America, a criterion of a minimum distance of $100 \mathrm{~km}$ between maxima is applied. Therefore, the identified lightning hotspots should be interpreted as a cluster of hotspots around a reference location. Also, it may exclude popular and wellknown locations as it chooses the closest populated place and not the place with the most inhabitants. More details on the ranking methodology and the complete list of the first 500 hotspots are shown in the online supplemental material. In Table 1, we show the top 10 lightning hotspots for each major continental landmass covered by LIS (North America, South America, Africa, Asia, and Oceania). Figure 2 shows the geographical distribution of the top 10 lightning hotspots of each major tropical continental landmass as well as a zoomed plot of the total lightning climatology (refer to Fig. 1) at each first continental landmass hotspot. ${ }^{2}$ Note that LIS measurements are limited to approximately $\pm 38^{\circ}$, such that continents are not observed in their entirety. The rankings are based on the portions of the continents observed by LIS.

Not surprisingly, Africa is represented by 283 of the top 500 places with the highest lightning frequency, followed by Asia with 87, South America with 67, North America with 53, and Oceania with 10 (Table ES3 of OSM). However, one surprising discovery is that Earth's top-ranked total lightning hotspot is not in Africa as reported previously but instead directly over Lake Maracaibo in Venezuela $\left(9.75^{\circ}\right.$, $-71.65^{\circ}$ ) where $233 \mathrm{fl} \mathrm{km}^{-2} \mathrm{yr}^{-1}$ occur, leaving the previously identified Congo basin hotspot in Africa (Christian et al. 2003; Goodman et al. 2007; Cecil et al. 2014) (more details in the OSM). in second place with $205 \mathrm{fl} \mathrm{km}^{-2} \mathrm{yr}^{-1}$. The closest populated place to this hotspot over Lake Maracaibo is Lagunillas in the state of Zulia on the east side of the lake, about $60 \mathrm{~km}$ away. Figure 2 shows that Earth's top-ranked maximum over Lake Maracaibo is very localized, covering an area of approximately $5,500 \mathrm{~km}^{2}$ with FRD greater than $50 \mathrm{fl} \mathrm{km}^{-2} \mathrm{yr}^{-1}$. This corresponds to only 45 pixels in $0.1^{\circ}$ resolution and less than 2 pixels in $0.50^{\circ}$ resolution and explains why it was not similarly identified in the previous lower-resolution $\left(0.5^{\circ}\right)$ LIS climatologies of Christian et al. (2003) and Cecil et al. (2014; more details in the OSM). The diurnal and annual cycles of lightning activity over Lake Maracaibo and other landmass hotspots are shown in Fig. 3. Lightning activity over Lake Maracaibo presents two peaks during the year, where most of the lightning occurs from August to November $\left(>65 \mathrm{fl} \mathrm{day}^{-1}\right)$, drastically decreasing in December with almost no lightning in January and February. The second peak is an approximately flat flash rate $\left(47 \mathrm{fl} \mathrm{day}^{-1}\right)$ in May and June and is related to the migration of the ITCZ (Pulwarty et al. 1998). The strong diurnal cycle of lightning frequency reveals almost no lightning during the day and a nocturnal

${ }^{2}$ Note that all 500 hotspots can be navigated (with zoom capability) using Google Earth API at the LIS Very High Resolution Climatology web page hosted by NASA GHRC at http:// lightning.nsstc.nasa.gov/data/data_lis-vhr-climatology.html. 
TABLE I. Top 10 FRD ( $\mathrm{fl} \mathrm{km}^{-2} \mathrm{yr}^{-1}$ ) for each continental landmass, indicating its position in the global ranking, latitude (Lat) and longitude (Lon) position on TRMM LIS $0.1^{\circ}$ climatology grid, as well as the name of the nearest populated place name (PPL), position (PPL lat, PPL lon), and distance from grid point (Dist), according to the GeoNames database (www.geonames.org/). A minimum distance of $100 \mathrm{~km}$ from a previous ranked grid point was applied.

\begin{tabular}{|c|c|c|c|c|c|c|c|c|}
\hline $\begin{array}{c}\text { Global } \\
\text { rank }\end{array}$ & FRD & $\begin{array}{c}\text { Lat } \\
\left(^{\circ}\right)\end{array}$ & $\begin{array}{c}\text { Lon } \\
\left({ }^{\circ}\right)\end{array}$ & PPL & Country & $\begin{array}{c}\text { PPL lat } \\
\left(\mathbf{(}^{\circ}\right)\end{array}$ & $\begin{array}{c}\text { PPL lon } \\
\left(\mathbf{(}^{\circ}\right)\end{array}$ & $\begin{array}{c}\text { Dist } \\
(\mathbf{k m})\end{array}$ \\
\hline
\end{tabular}

\section{South America}

\begin{tabular}{|r|r|r|r|c|c|r|r|r|}
\hline I & 232.52 & 9.75 & -71.65 & $\begin{array}{c}\text { Lake Maracaibo } \\
\text { (Lagunillas) }\end{array}$ & Venezuela & 10.13 & -71.26 & 60.1 \\
\hline 4 & 172.29 & 7.55 & -75.35 & Cáceres & Colombia & 7.58 & -75.35 & 3.4 \\
\hline 7 & 138.61 & 8.85 & -73.05 & El Tarra & Colombia & 8.58 & -73.09 & 30.9 \\
\hline II & 124.26 & 5.75 & -74.95 & Norcasia & Colombia & 5.58 & -74.89 & 20.4 \\
\hline 18 & 114.19 & 8.45 & -74.55 & Majagual & Colombia & 8.54 & -74.62 & 12.6 \\
\hline 25 & 105.73 & 8.15 & -76.85 & Turbo & Colombia & 8.09 & -76.73 & 14.8 \\
\hline 46 & 95.38 & 11.15 & -72.95 & Barrancas & Colombia & 10.96 & -72.79 & 27.8 \\
\hline 74 & 87.96 & -17.25 & -65.05 & Chimoré & Bolivia & -16.95 & -65.14 & 34.9 \\
\hline 78 & 87.61 & 10.35 & -70.95 & El Corozo & Venezuela & 10.12 & -71.04 & 27.5 \\
\hline 136 & 77.02 & 10.45 & -75.35 & Santa Rosa & Colombia & 10.44 & -75.37 & 2.2 \\
\hline
\end{tabular}

\begin{tabular}{|c|c|c|c|c|c|c|c|c|}
\hline \multicolumn{9}{|c|}{ Africa } \\
\hline 2 & 205.31 & -1.85 & 27.75 & Kabare & $\begin{array}{c}\text { Democratic Republic } \\
\text { of the Congo }\end{array}$ & -2.50 & 28.79 & 136.2 \\
\hline 3 & $176.7 \mid$ & -3.05 & 27.65 & Kampene & $\begin{array}{c}\text { Democratic Republic } \\
\text { of the Congo }\end{array}$ & -3.60 & 26.67 & 124.9 \\
\hline 5 & 143.21 & -0.95 & 27.95 & Sake & $\begin{array}{l}\text { Democratic Republic } \\
\text { of the Congo }\end{array}$ & -1.57 & 29.04 & 140.0 \\
\hline 8 & 129.58 & 5.25 & 9.35 & Nguti & Cameroon & 5.33 & 9.42 & 11.7 \\
\hline 9 & 129.50 & 0.25 & 28.45 & Butembo & $\begin{array}{c}\text { Democratic Republic } \\
\text { of the Congo }\end{array}$ & 0.14 & 29.29 & 94.3 \\
\hline 10 & 127.52 & -1.55 & 20.95 & Boende & $\begin{array}{l}\text { Democratic Republic } \\
\text { of the Congo }\end{array}$ & -0.28 & 20.88 & 141.2 \\
\hline 14 & 117.98 & 0.55 & 20.35 & Boende & $\begin{array}{c}\text { Democratic Republic } \\
\text { of the Congo }\end{array}$ & -0.28 & 20.88 & 109.7 \\
\hline 15 & 117.19 & -2.45 & 26.95 & Kindu & $\begin{array}{c}\text { Democratic Republic } \\
\text { of the Congo }\end{array}$ & -2.94 & 25.92 & 126.7 \\
\hline 16 & 116.78 & 6.95 & 10.45 & Baissa & Nigeria & 7.23 & 10.63 & 36.6 \\
\hline 19 & 112.17 & 0.35 & 26.65 & Kisangani & $\begin{array}{c}\text { Democratic Republic } \\
\text { of the Congo }\end{array}$ & 0.52 & 25.19 & 163.3 \\
\hline
\end{tabular}

\begin{tabular}{|c|r|r|r|c|c|c|c|c|}
\hline \multicolumn{10}{|c|}{ Asia } \\
\hline 6 & 143.11 & 34.45 & 72.35 & Daggar & Pakistan & 34.51 & 72.48 & 14.0 \\
\hline 12 & 121.41 & 33.35 & 74.55 & Rājauri & India & 33.38 & 74.31 & 22.6 \\
\hline 13 & 118.81 & 33.75 & 70.75 & Doāba & Pakistan & 33.42 & 70.74 & 36.2 \\
\hline 22 & 108.03 & 14.55 & 43.45 & Al Hadīyah & Yemen & 14.53 & 43.57 & 13.2 \\
\hline 28 & 104.59 & 33.85 & 73.25 & Murree & Pakistan & 33.91 & 73.39 & 14.5 \\
\hline 31 & 101.79 & 25.25 & 91.95 & Cherrapunji & India & 25.30 & 91.70 & 26.1 \\
\hline 42 & 97.02 & 4.75 & 103.05 & Paka & Malaysia & 4.64 & 103.44 & 44.7 \\
\hline 45 & 95.92 & 1.95 & 103.85 & Kota Tinggi & Malaysia & 1.74 & 103.90 & 24.2 \\
\hline 50 & 94.64 & 3.75 & 98.05 & Tenggulun & Indonesia & 3.99 & 98.01 & 27.3 \\
\hline 52 & 93.96 & 3.15 & 101.65 & Kuala Lumpur & Malaysia & 3.14 & 101.69 & 4.2 \\
\hline
\end{tabular}




\begin{tabular}{|c|c|c|c|c|c|c|c|c|}
\hline $\begin{array}{l}\text { Global } \\
\text { rank }\end{array}$ & FRD & Lat $\left({ }^{\circ}\right)$ & $\begin{array}{l}\text { Lon } \\
\left({ }^{\circ}\right)\end{array}$ & PPL & Country & $\begin{array}{c}\text { PPL lat } \\
\left({ }^{\circ}\right)\end{array}$ & $\begin{array}{l}\text { PPL lon } \\
\left({ }^{\circ}\right)\end{array}$ & $\begin{array}{l}\text { Dist } \\
(\mathbf{k m})\end{array}$ \\
\hline \multicolumn{9}{|c|}{ North America } \\
\hline 17 & 116.76 & 14.35 & -91.15 & Patulul & Guatemala & 14.42 & -91.17 & 7.6 \\
\hline 29 & 103.23 & 14.85 & -92.05 & Catarina & Guatemala & 14.85 & -92.08 & 2.8 \\
\hline 33 & 100.63 & 22.35 & -83.95 & San Luis & Cuba & 22.29 & -83.77 & 20.1 \\
\hline 34 & 100.24 & 18.55 & -74.35 & Chambellan & Haiti & 18.57 & -74.32 & 4.0 \\
\hline 37 & 99.39 & 13.15 & -87.25 & San Jerónimo & Honduras & 13.18 & -87.14 & 12.7 \\
\hline 39 & 98.22 & 22.35 & -80.65 & Rodas & Cuba & 22.34 & -80.56 & 9.8 \\
\hline 40 & 98.06 & 21.75 & -78.85 & Venezuela & Cuba & 21.74 & -78.80 & 5.8 \\
\hline 47 & 95.32 & 22.85 & -82.15 & Mañalich & Cuba & 22.81 & -82.15 & 4.3 \\
\hline 82 & 86.96 & 22.25 & -105.25 & Rosamorada & Mexico & 22.12 & -105.21 & 14.9 \\
\hline 90 & 85.78 & 18.15 & -77.65 & Balaclava & Jamaica & 18.17 & -77.64 & 2.6 \\
\hline \multicolumn{9}{|c|}{ Oceania } \\
\hline 61 & 92.15 & -15.35 & 125.35 & Derby & Australia & -17.30 & 123.63 & 284.4 \\
\hline 83 & 86.75 & -14.45 & 126.55 & Kununurra & Australia & -15.78 & 128.74 & 278.0 \\
\hline 228 & 65.11 & -16.65 & 124.75 & Derby & Australia & -17.30 & 123.63 & 139.6 \\
\hline 308 & 59.69 & -15.65 & 128.45 & Kununurra & Australia & -15.78 & 128.74 & 34.6 \\
\hline 316 & 59.19 & -4.75 & 142.95 & Ambunti & Papua New Guinea & -4.22 & 142.82 & 61.0 \\
\hline 327 & 58.57 & -15.25 & 129.45 & Kununurra & Australia & -15.78 & 128.74 & 95.8 \\
\hline 355 & 57.13 & -13.15 & 131.05 & McMinns Lagoon & Australia & -12.55 & 131.11 & 66.6 \\
\hline 381 & 55.57 & -13.95 & 129.95 & Darwin & Australia & -12.46 & 130.84 & 191.6 \\
\hline 471 & 51.35 & -19.15 & 137.85 & Mount Isa & Australia & -20.73 & 139.50 & 245.6 \\
\hline 477 & 51.22 & -17.45 & 126.05 & Halls Creek & Australia & -18.22 & 127.67 & 191.6 \\
\hline
\end{tabular}

maximum $\left(>2.5 \mathrm{fl} \mathrm{h}^{-1}\right)$ from 0000 to 0500 LST abruptly peaking $\left(5.4 \mathrm{fl} \mathrm{h}^{-1}\right)$ at $0300 \mathrm{LST}$ (Fig. 3a).

South America. Of South America's top 10 hotspots (including Earth's top hotspot at Lake Maracaibo), 7 are located near or at the valleys or foothills of the northern Andes Mountains in Colombia, Venezuela, and Bolivia (Fig. 2). All these hotspots, except the one in Bolivia, have similar annual and diurnal cycles of lightning activity (Figs. 1c, 3a), with most lightning activity (>15 fl day ${ }^{-1}$ ) from austral fall [March-May (MAM)] to austral spring [September-November (SON)] with a peak in August or September (37-88 $\mathrm{fl} \mathrm{day}^{-1}$ ) and most lightning occurring during the night $\left(>2 \mathrm{fl} \mathrm{h}^{-1}\right)$. Nocturnal maxima of deep convection were also observed by other authors over the valleys along the most northern portion of the Andes Mountains, including Lake Maracaibo (Garreaud and Wallace 1997; Negri et al. 2000; Mapes et al. 2003a; Poveda et al. 2005; Bürgesser et al. 2012; Virts et al. 2013). These authors attributed the nocturnal convection to local thermally driven circulations (land-sea breezes and mountain-valley breezes) that provide low-level convergence inside the valleys and offshore (Gulf of Panama) as well as convergence of gravity waves from diurnally varying heat sources (differential heating between land, lake, mountain, and valleys; Mapes et al. 2003a). Lightning activity in the Bolivian hotspot (Chimoré) is from austral spring to summer $\left(>5 \mathrm{fl} \mathrm{day}^{-1}\right.$, peaking in November, $30 \mathrm{fl} \mathrm{day}^{-1}$; Fig. 3b) without a well-defined diurnal cycle $\left(0.5-1.0 \mathrm{fl} \mathrm{h}^{-1}\right.$ from 1300 to 0400 LST; Fig. 3a). This hotspot is also at the eastern side of the Andes' foothills, at the end of the northwest-southeast-orientated range, inside Carrasco National Park. In this configuration, the mountains are a natural barrier to the moist South American Low-Level Jet winds from the Amazon basin (Vera et al. 2006), forcing it uphill and favoring thunderstorm development during spring and summer. Inferred peaks of hailstorm frequency, based on passive microwave observations from satellite, were also found by Cecil and Blankenship (2012) at this same spot during spring and summer. Four hotspots (sixth, seventh, ninth, and tenth) are located 

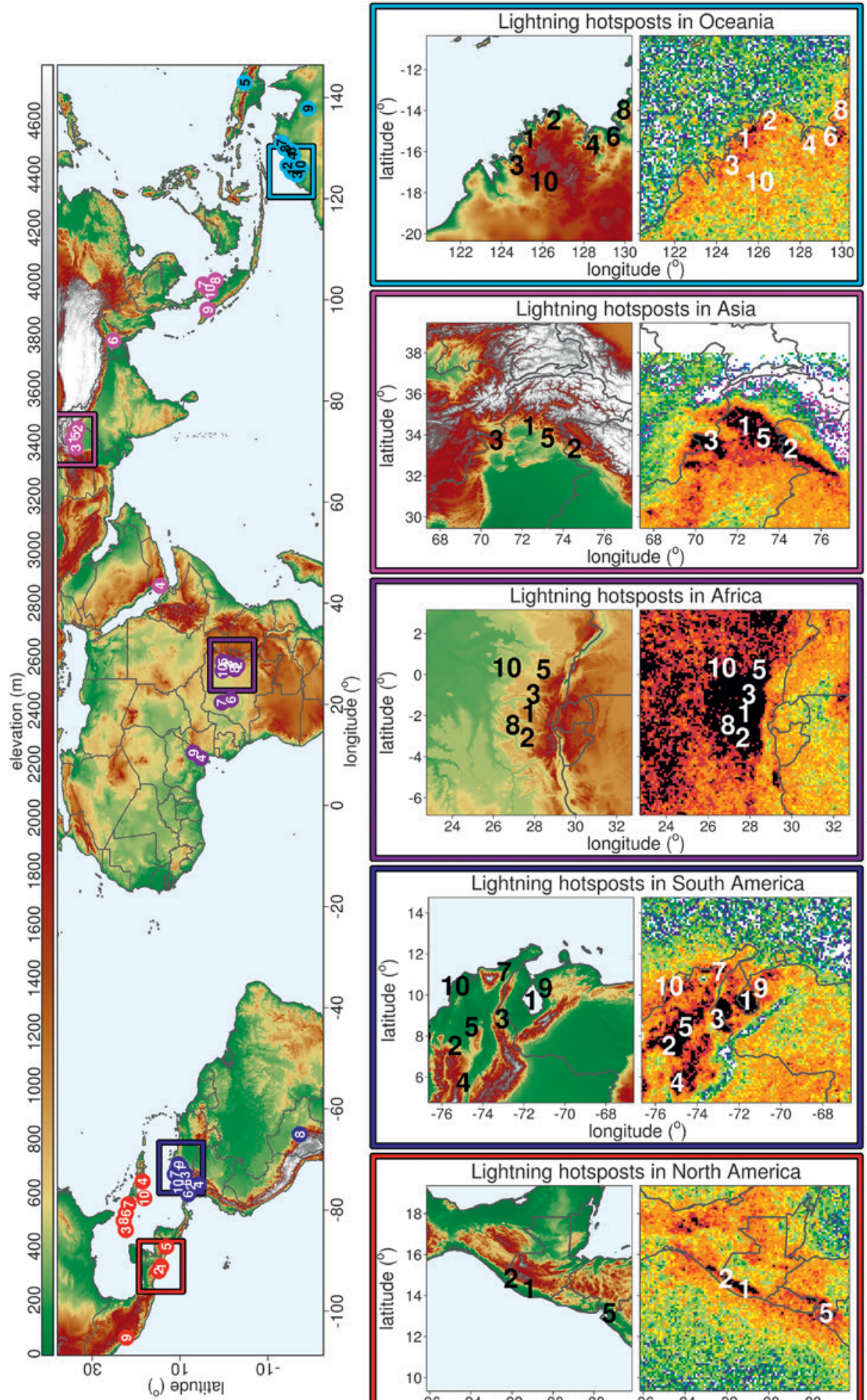

웃
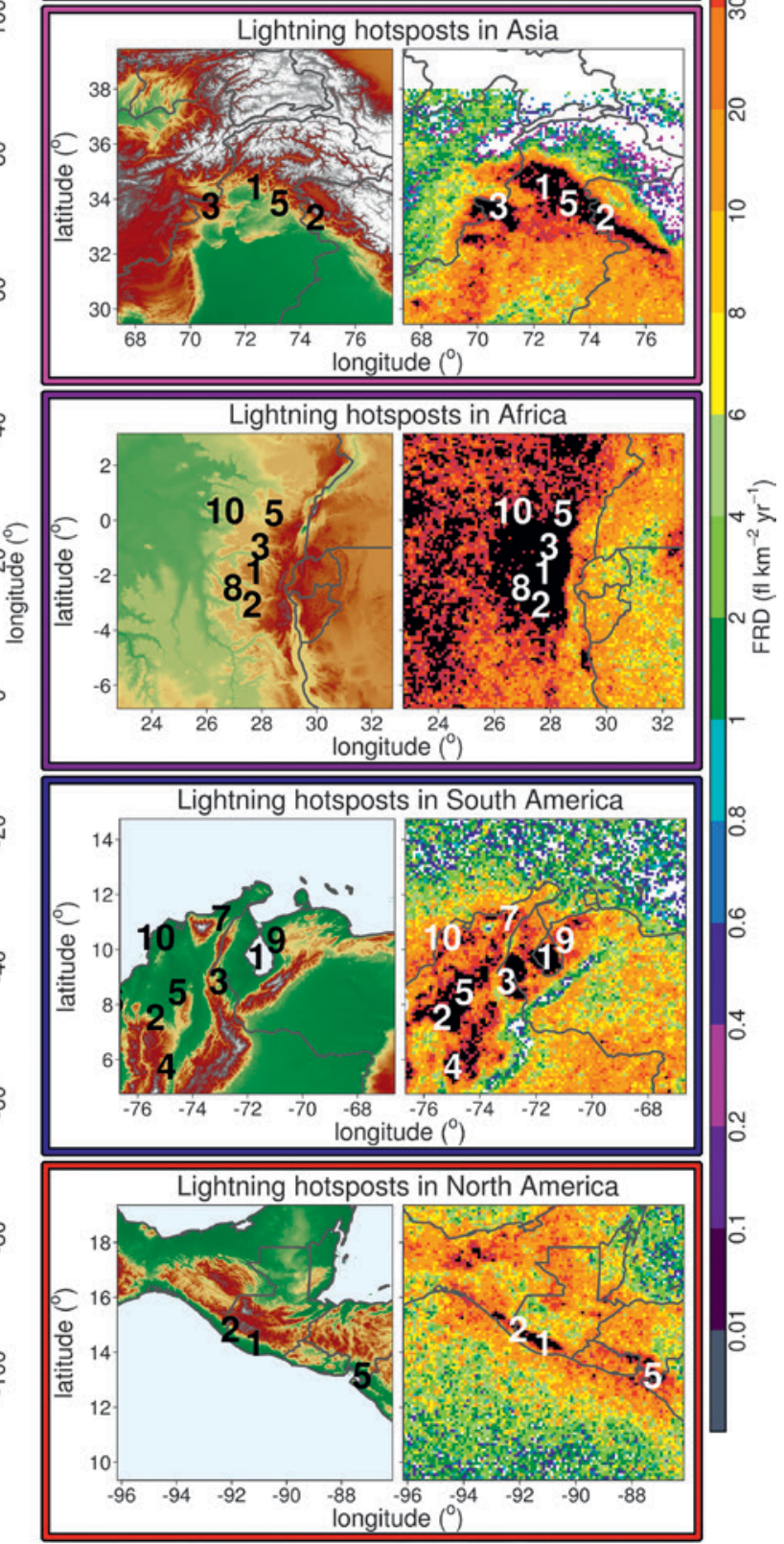

FIG. 2. (left) Location (numbered symbols) of the top IO FRD hotspots per major continental landmasses (Africa, Asia, North America, Oceania, and South America), and (right) $2.5^{\circ}$ zoom boxes on FRD climatology of each landmass first hotspot (Table I), using the same FRD color coding as in Fig. Ia. Numbered symbols indicate the continent landmass ranking order (first to tenth) from Table I, and colors indicate the continent (purple indicates Africa, magenta indicates Asia, blue indicates North America, light blue indicates Oceania, and red indicates South America). Shaded color scale in the left and central figures is terrain elevation. 
near the Colombia and Venezuela coasts, presenting the same annual cycle as most of the top 10 South American hotspots. However, those hotspots farther to the west (seventh and ninth) have afternoon peaks $\left(>2 \mathrm{fl} \mathrm{h}^{-1}\right)$ at 1700 LST due to a well-defined diurnal cycle and sea breeze near elevated terrain (Fig. 2; South America zoom at Lake Maracaibo).

Africa. Earth's second greatest lightning hotspot is at Kahuzi-Biéga National Park $\left(-1.85^{\circ}, 27.75^{\circ}\right)$, (a) Hourly flash rate at top 10 hotspots
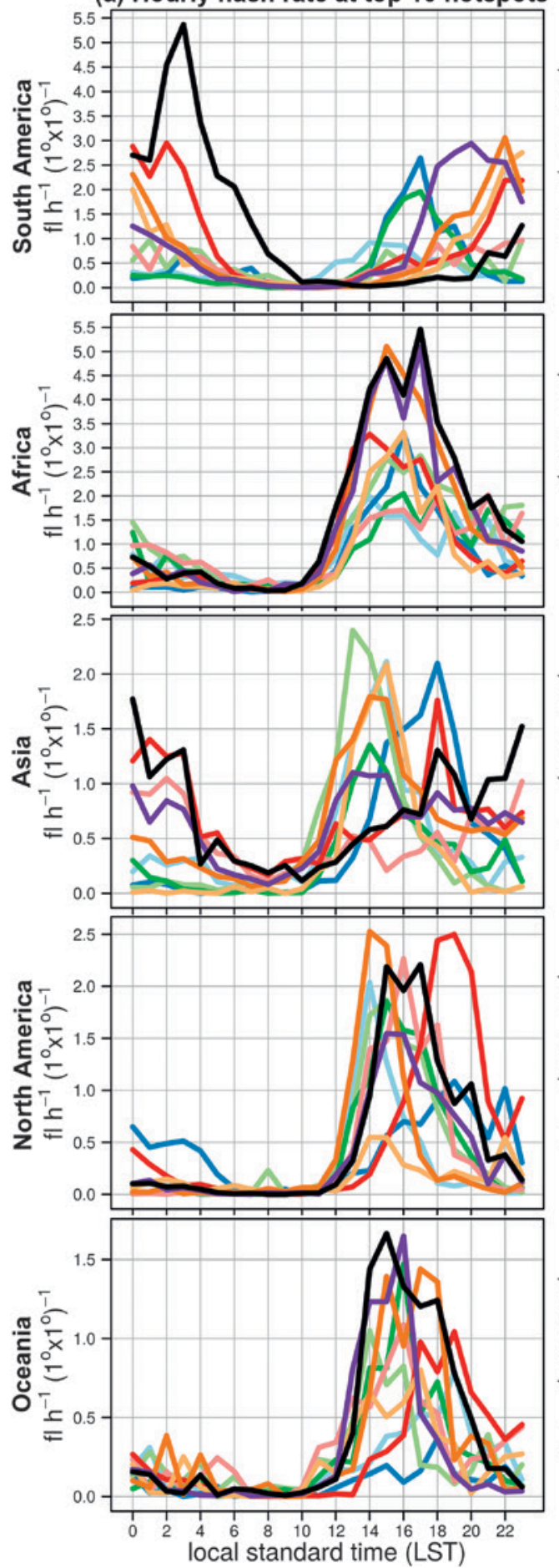

(b) Daily flash rate at top 10 hotspots
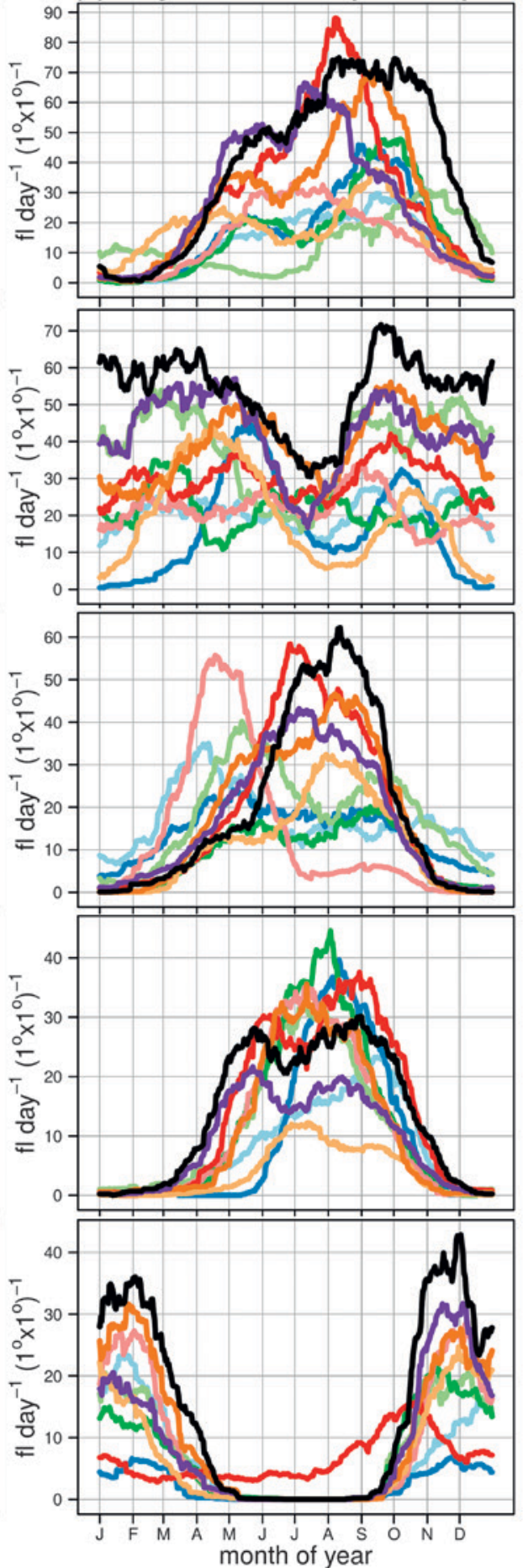

1) Lake Maracaibo, VE

2) Cáceres, co

3) EI Tarra, co

4) Norcasia, CO

5) Majagual, $\mathrm{CO}$

6) Turbo, co

7) Barrancas, co

8) Chimoré, BO

9) El Corozo, VE

10) Santa Rosa, CO

1) Kabare, $C D$

2) Kampene, $C D$

3) Sake, CD

4) Nguti, CM

5) Butembo, $C D$

6) Boende, $C D$

7) Boende, $C D$

8) Kindu, CD

9) Baissa, NG

10) Kisangani, $C D$

1) Daggar, $\mathrm{PK}$

2) Rảjauri, IN

3) Doāba, PK

4) Al Hadiyah, YE

5) Murree, PK

6) Cherrapunji, IN

7) Paka, MY

8) Kota Tinggi, MY

9) Tenggulun, ID

10) Kuala Lumpur, MY

1) Patulul, GT

2) Catarina, GT

3) San Luis, CU

4) Chambellan, HT

5) San Jerónimo, HN

6) Rodas, CU

7) Venezuela, cU

8) Mañalich, $\mathrm{CU}$

9) Rosamorada, MX

10) Balaclava, JM

1) Derby, AU

2) Kununurra, $A U$

3) Derby, AU

4) Kununurra, $A U$

5) Ambunti, PG

6) Kununurra, $A U$

7) McMinns Lagoon, AU

8) Darwin, AU

9) Mount Isa, AU

10) Halls Creek, AU

FIG. 3. (a) Hourly and (b) daily flash rate density distribution of the top 10 lightning hotspots of each major continental landmass from Table I. These values are calculated over a $I^{\circ}$ box centered at the hotspot. 
$136.2 \mathrm{~km}$ northwest of Kabare in the Democratic Republic of the Congo near the border of Rwanda (on the west side of the Mitumba Mountains; Fig. 2). The Mitumba Mountains at the eastern edge of the Congo basin mark the beginning of the Western Rift Valley in East Africa, along a north-south orientation at $\sim 29^{\circ} \mathrm{E}$ and with peaks ranging from 2,000 to $5,200 \mathrm{~m}$. Total lightning flash rate densities greater than $50 \mathrm{fl} \mathrm{km} \mathrm{yr}^{-1}$ are observed along a continuous large area $\left(\sim 320,000 \mathrm{~km}^{2}\right)$ on the western foothills of these mountains from $4^{\circ} \mathrm{S}$ to $5^{\circ} \mathrm{N}$, having 6 out of the 10 African hotspots. The FRD decreases westward of $25^{\circ} \mathrm{E}$ to a narrow region of $40-50 \mathrm{fl} \mathrm{km}^{-2} \mathrm{yr}^{-1}$ and

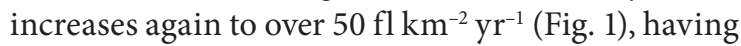
two other African hotspots. All the hotspots over the Mitumba Mountains exhibit higher mean diurnal cycle flash rates (Fig. 3b) during the afternoon (peak of $5 \mathrm{fl} \mathrm{h}^{-1}$ from 1500 to 1700 LST) than in the central Congo ( $3 \mathrm{fl} \mathrm{h}^{-1}$ at $\left.1500 \mathrm{LST}\right)$, with some activity during the night $\left(\sim 1 \mathrm{fl} \mathrm{h}^{-1}\right)$ probably associated with the maximum extent of MCSs (Laing and Fritsch 1993; Jackson et al. 2009).

Thunderstorms occur year-round in central and western Africa, but these regions are electrically more active from September to May, with flash rates over $15 \mathrm{fl}$ day $^{-1}$ occurring on most days, with less lightning activity observed in July (Fig. 3b). The spatial and temporal distributions of African rainfall, and therefore also lightning activity, are tied to a combination of large- and local-scale factors, such as the seasonal migration of the ITCZ, the position of the African easterly jets (which migrate seasonally with the ITCZ and are evident from August to November), long nocturnal life cycle of MCSs, afternoon boundary layer destabilization, local effects of sea breezes and topography, as well as the sea surface temperatures (Nicholson 1996; Yin and Nicholson 2000; Nicholson and Grist 2003; Balas and Nicholson 2007; Jackson et al. 2009; Nicholson 2009). Particularly, from August to November, the African easterly jet of the Northern Hemisphere (AEJ-N) and the African easterly jet of the Southern Hemisphere (AEJ-S) are well developed and located, respectively, above and below the edges of the Mitumba mountain range. In addition, there is a strong low-level moisture convergence on its lee side, coming from the Atlantic and central Congo rain forest (Jackson et al. 2009). This mesoscale configuration results in a convergence region with strong vertical motions on the right entrance of the AEJ-S, which, along with the deep low-level moisture source, promotes an explosive convection scenario for thunderstorm and lightning development over the whole of the Congo basin
(Nicholson 1996; Jackson et al. 2009). This is reflected in the lightning maximum ranking (Table 1), where 8 of the 10 most active lightning places in Africa occur within the Democratic Republic of the Congo, all having FRD greater than $110 \mathrm{fl} \mathrm{km}^{-2} \mathrm{yr}^{-1}$. The two African hotspots at the Cameroon border (Nguti, Cameroon, and Baissa, Nigeria) have their diurnal cycle influenced by local afternoon convection driven by sea-breeze and moisture flux convergence from the Gulf of Guinea (Nicholson 2009).

Asia. High to very high FRD $\left(>30 \mathrm{fl} \mathrm{km}^{-2} \mathrm{yr}^{-1}\right)$ can be found at the high elevation envelope along the length of the Himalayas in Asia. Asia's top-ranked lightning hotspot, Daggar, Pakistan $\left(34.45^{\circ}, 72.35^{\circ}\right)$, is located in the westernmost portion of the Himalayas foothills at the Indus' Plain, more specifically at the Hindu Kush range in the northernmost region of Pakistan (Fig. 2). Three other Asian hotspots (the second, third, and fifth highest) are also located in this region, whereas the sixth Asian hotspot is at the most eastern portion of Himalayas, at the Kashi Hills (on the border between India and Bangladesh). The western Himalayas were also identified as a region with the most intense thunderstorms on Earth by Cecil et al. (2005), Zipser et al. (2006), and Houze et al. (2007). Houze et al. (2007) found that the deepest intense convective storms occur upwind or at the foothills of the mountains, where the moist southwesterly monsoon flow from the Arabian Sea meets the descending dry air from the Afghan or Tibetan Plateaus, suggesting a similarity to dryline convection. All these hotspots have more lightning activity $\left(>15 \mathrm{fl} \mathrm{day}^{-1}\right)$ during the monsoon months (May-October, peaking in September; Fig. 3) and less from November to March, with the most lightning activity extending from late afternoon (1600 LST) to early morning (0600 LST), with the exception of the second- and third-ranked hotspots. The nocturnal lightning is controlled by a few MCSs and local convection induced by the interaction between the largescale synoptic flow and the complex terrain (Barros and Lang 2003; Barros et al. 2004; Zipser et al. 2006; Houze et al. 2007). Barros et al. (2004) found that two types of orographic terrain control cloudiness in the Himalayan range: the first type is associated with the major river valleys ( $\sim 300 \mathrm{~km}$ wide) and the overall mountain range that connects India and the Tibetan Plateau, while the second type is associated with the succession of ridges and small valleys ( $5-150 \mathrm{~km}$ wide). In fact, Fig. la shows a long, nearly contiguous line and a broken line of FRD greater than $30 \mathrm{~km}^{-2} \mathrm{yr}^{-1}$ within the Himalayan river valleys and the narrow valleys, respectively, in northern India and Nepal, with 
an indistinct local hour of maximum lightning activity (Fig. 1b) at night and early morning. At high elevations over the Tibetan Plateau, the local hour of maximum is during the day.

The remaining Asian hotspots, except for the one in Yemen, lie over the coasts of Malaysia and Sumatra Island (Indonesia) and are caused by a sea breeze resulting in the afternoon (peak at 1500 LST; Fig. 3a) in FRD. Figure 4 shows daytime and nighttime FRD over Malaysia and

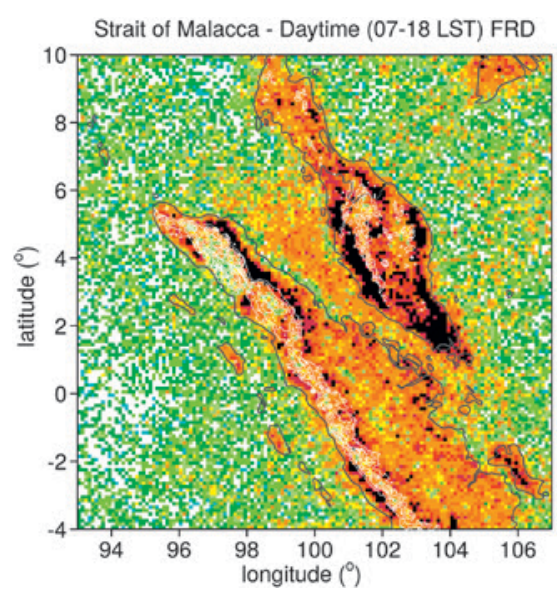

Strait of Malacca- Nighttime (19-06 LST) FRD

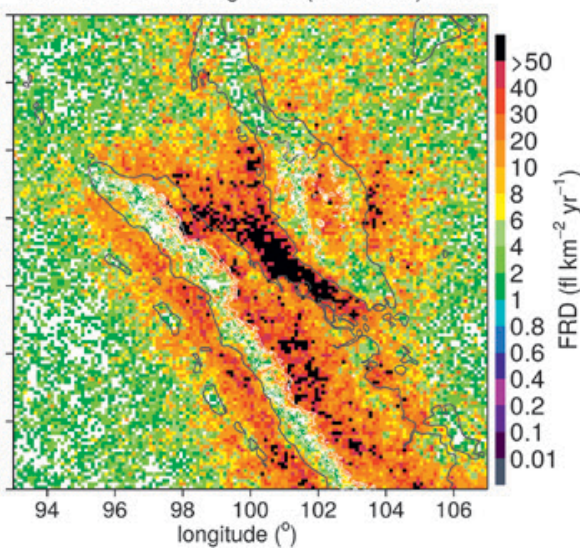

FIG. 4. Daytime (0700-1800 LST) and nighttime (1900-0600) flash rate density $\left(\mathrm{fl} \mathbf{~ k m}^{-2} \mathrm{yr}^{-1}\right)$ at the Strait of Malacca, Indonesia. White lines are elevation from 500 to $3,000 \mathrm{~m}$ in $\mathbf{5 0 0}-\mathrm{m}$ intervals, and gray lines are country physical boundaries.
Sumatra Island. High FRD

greater than $50 \mathrm{fl} \mathrm{km}^{-2} \mathrm{yr}^{-1}$ is found inland, alongside the coast and high elevated terrain. During the night, convergent offshore breezes from the peninsular Malaysia and the Sumatra Island over the Strait of Malacca leads to increased FRD over the ocean after midnight (Fig. 1b), also seen in cloud-to-ground lighting activity (Virts et al. 2013). The annual cycle shows two peaks during the year associated with the ITCZ migration from the Northern to the Southern Hemispheres (Fig. 3b). The hotspot at Yemen [Al Hadiyah $\left(14.55^{\circ}, 43.45^{\circ}\right)$ ] also presents a maximum of activity in the afternoon because of the sea breeze, but its annual cycle shows lesser lightning activity $\left(<30 \mathrm{fl} \mathrm{day}^{-1}\right)$ peaking in August.

North America. In North America, the first and second hotspots with FRD $>100 \mathrm{fl} \mathrm{km}^{-2} \mathrm{yr}^{-1}$ (respectively, Patalul and Catarina, in Guatemala) as well as the ninth hotspot (Rosamorada, Mexico) are also at the foothills of a mountain range, the Sierra Madre, in a very narrow low-level strip of land between the Pacific Ocean and the mountains. These hotspots show an afternoon lightning peak with most of the lightning activity occurring during boreal spring and summer. All remaining North American hotspots are over the Central America islands (Cuba, Honduras, Haiti, and Jamaica) that also exhibit afternoon lightning activity occurring mostly during spring and summer.

The top U.S. hotspot with an FRD of $79 \mathrm{fl} \mathrm{km}^{-2} \mathrm{yr}^{-1}$ lies over the Everglades near Orangetree, Florida, about $37 \mathrm{~km}$ from Fort Meyers. The top U.S. hotspot is ranked only 14th in North America (122nd globally). This same location coincides with that found in the first thunderstorm day climatology constructed by
Court and Griffiths (1982). These authors compiled the number of thunderstorm days recorded by surface weather stations around the globe from 1951 to 1975 and found that Fort Meyers, Florida, is the place with the most thunderstorm days per year (96) in the United States, with a peak in July.

Oceania. Oceania hotspots all are found at the northern coast of Australia, except the fifth most active locale that is found in Papua New Guinea. Most of the FRD across Australia and Papua New Guinea is less than $10 \mathrm{fl} \mathrm{km}^{-2} \mathrm{yr}^{-1}$ and is attributable to local convection in the afternoon, mostly during austral summer monsoon with two peaks (December and mid-January to March; Fig. 3b; Jayaratne and Kuleshov 2006; Kuleshov et al. 2006), in contrast to the other two monsoonal regimes of the Amazon and India that exhibit lightning peaks during premonsoon. The diurnal cycle of the hotspot at Ambunti, Papua New Guinea, also exhibits lightning maximum during the afternoon (Fig. 3a), but its annual cycle shows much lower FRD than Australia, peaking 2 months earlier (October) than Australia hotspots. It is worthwhile to note that North America's and Oceania's top hotspots have an FRD that is barely on the order of Africa's tenth-ranked hotspot $\left(\sim 100 \mathrm{fl} \mathrm{km}^{-2} \mathrm{yr}^{-1}\right)$. This reflects the greater occurrence of convection and lightning activity in tropical belts of Africa, South America, and Asia.

\section{EARTH'S TOP LIGHTNING HOTSPOT.}

Nocturnal thunderstorms over Lake Maracaibo are so frequent that their lightning activity was used as a lighthouse by Caribbean navigators in colonial times 
(Codazzi 1841), and they are also mentioned in the La Dragontea (1598) poem, from the Spanish poet Felix Lope De Vega, as what prevented an English pirate from attacking Maracaibo. These thunderstorms are locally known as the "Lighthouse of Catatumbo," the "Never-Ending Storm of Catatumbo," or simply Catatumbo lightning. Catatumbo is a river that ends southwest of Maracaibo Lake, and nowadays tourists can take nighttime boat tours to observe these beautiful storms.

Lake Maracaibo has a unique set of features that contributes to the development of deep convection at the same place 297 days per year on average (Fig. 3b) with a maximum at night (Fig. 3a). This lake is the largest in South America, with an area of $13,210 \mathrm{~km}^{2}$, and is located between the most northern ridges of the Andes Mountains (Fig. 5). At its northern portion, the
Andes are branched out, defining several large valleys over Colombia, and form a large valley in which lies Lake Maracaibo. The lake is connected to the Gulf of Venezuela at its northern end, near Maracaibo city, and the very warm water temperatures over the lake and at the gulf throughout the year $\left(28^{\circ}-31^{\circ} \mathrm{C}\right)$, with its maximum in September (Muñoz et al. 2008), serve as a great source of heat and moisture for convection.

All these geographical features combined with convergent wind flow (mountain-valley, lake, and land-sea breezes) over this warm, humid lake within the ITCZ make an ideal spot for thunderstorm development. During the day, radiative heating by the sun causes the land surrounding the lake to become hotter than the lake, inducing a lake-breeze circulation with subsidence over Lake Maracaibo. In addition, the sides of the mountains warm up more rapidly than

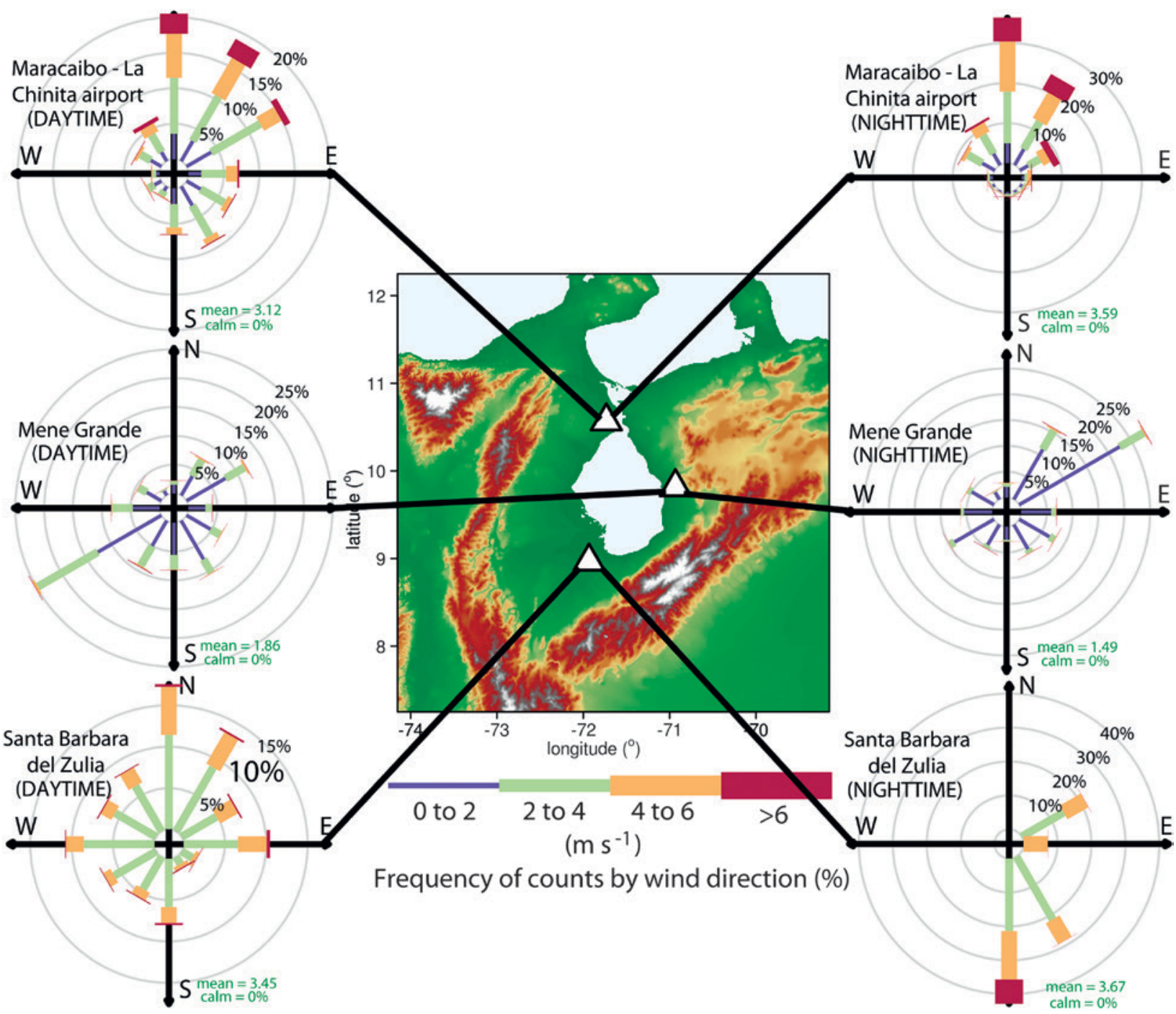

FIG. 5. (middle) Northwestern Venezuela elevation map as well as (left) daytime and (right) nighttime wind roses from three locations around Lake Maracaibo: Zulia, Mene Grande, and Maracaibo. Elevation color scale is the same as in Fig. 2. 
the valley, thereby inducing a valley breeze accompanied by subsidence over the lake, inhibiting convection. This can be seen in the diurnal distribution of FRD over this region in Fig. 6a. Lightning activity is only observed over a small area of the lake during the late afternoon. Most of the daytime lightning occurs near the coast and is driven by a sea-breeze circulation that is forced uphill to higher elevations. On the other hand, during the night, radiative cooling causes the land to become cooler than the lake with the surrounding mountainsides cooling more rapidly than the valley, yielding a low-level wind convergence over the hot and humid environment of the lake.

Figure 5 shows wind roses (frequency of wind speed by wind direction) of surface weather station data during daytime (0700-1800 LST) and nighttime (1900-0600 LST) at three locations around Lake Maracaibo (Zulia, Mene Grande, and Maracaibo) for the period 1998-2014. This dataset is freely available online through NOAA/National Climatic Data Center's Integrated Surface Database (ISD; www.ncdc .noaa.gov/isd). ISD consists of surface observations from over 35,000 stations worldwide, compiled from numerous sources into a single common data format (Lott et al. 2008). It can be seen that, in general, the wind indeed blows toward the lake during the night and away from the lake during the day. This results in a nighttime convergent land-lake breeze and a daytime divergent lake-land breeze over the lake. This is a perfect combination for nocturnal thunderstorm development and very high flash rate occurrence, where FRD above $50 \mathrm{fl} \mathrm{km} \mathrm{yr}^{-1}$ covers most of the lake area, the southwestern portion of the valley and also several valleys in Colombia during nighttime (Fig. 6a).

The two flash rate peaks from August to October and May to July coincide with the weakening of the Caribbean low-level jet (CLLJ). The CLLJ is characterized by a predominantly easterly wind with a maximum at the central Caribbean Sea between $12^{\circ}$ and $16^{\circ} \mathrm{N}$ and $71^{\circ}$ and $76^{\circ} \mathrm{W}$. This low-level jet increases vertical shear that reduces convection in June-July and December-March (Amador 1998; Wang 2007; Amador 2008; Muñoz et al. 2008, 2016), coinciding with the two lightning minima observed over Lake Maracaibo (Fig. 3b). The weakening of CLLJ in September-November and May (as a response from the smaller gradient in sea level pressure and sea surface temperature in the Caribbean Sea) favors convection and is responsible for the rainy season over northern South America and southern Central America (Mapes et al. 2003b; Muñoz et al. 2008, 2016). This decrease in vertical shear increases air mass thunderstorm development in Lake Maracaibo, contributing to the frequent lightning activity in August-October and April-May.

The persistent low-level convergence over the warm waters of Lake Maracaibo almost all year long is a perfect scenario for development of thunderstorms and lightning production that contributes to the observed high FRD. Nocturnal convection and lightning activity over Lake Maracaibo have been 
reported in the literature by previous authors (Mapes et al. 2003b; Martinez et al. 2003; Albrecht et al. 2011a; Falcon 2011; Bürgesser et al. 2012). Several other inland lakes with similar conditions, that is, deep nocturnal convection driven by locally forced convergent flow over a warm lake surface, were identified in the LIS climatology. Lake Victoria, in Africa, is one of them. It is the largest tropical lake in the world, with an area of approximately $68,800 \mathrm{~km}^{2}$. This lake is located east of the Mitumba Mountains, in between the two branches of Rift Valley, and is divided among Tanzania, Uganda, and Kenya. As with Lake Maracaibo, Lake Victoria lightning activity is more pronounced during the night. Maximum convection and rainfall occurring during the night to early morning has long been recognized by studies dating from the 1960s. This nighttime maximum has been attributed to convergent nocturnal land breezes (e.g., Flohn and Fraedrich 1966; Ba and Nicholson 1998; Yin and Nicholson 2000; Nicholson and Yin 2002). Ba and Nicholson (1998) found that maximum convection occurs during the morning (0500-0800 LST) with a second peak in the afternoon, while over the surrounding land, maximum convection is observed in the afternoon and evening. These findings are corroborated by the daytime and nighttime FRD over Lake Victoria (shown in Fig. 6b). According to Flohn and Fraedrich (1966) and Nicholson and Yin (2002), because of prevailing easterly low-level winds, convection generally moves from the eastern surrounding land in the late afternoon toward the northeastern portion and center of the lake during the night and then toward the western portion of the lake during late night and early afternoon. In addition, other African Rift Valley lakes such as Tanganyika, Malawi, and Albert show nocturnal convergent land breeze (Nicholson and Yin 2002) with the LIS lightning activity peaks during the late night and early morning (Fig. 1b).

SUMMARY AND CONCLUSIONS. The 16 years of TRMM LIS lightning measurements are used to construct a very high-resolution $\left(0.1^{\circ}\right)$ total (cloud to ground and intracloud) lightning climatology. The derived lightning flash rate density maps reconfirm the previous general observations of continental deep convection over land and reduced lightning activity over the ocean with greater detail on mountainous regions such as the Andes, Himalayas, Sierra Madre, and Mitumba Mountains in Africa, all of which are marked by the frequent occurrence of thunderstorms at their foothills. The diurnal cycle over most continental regions presents the lightning maximum during the afternoon, with exceptions driven by locally forced circulations (such as mountain-valley and land-lake breezes) and nocturnal development of MCSs. The month of maximum flash rate density shows most lightning occurrence during summer months, except for strong monsoonal regions, as with India and the Amazon where lightning maximum activity occurs during springtime (premonsoon months) and in the case of India also in the postmonsoon months.

Finally, we identify Earth's lightning hotspots by ranking the climatological flash rate density, as well as the top 10 hotspots of each continental landmass, to highlight details of their annual and diurnal cycle of lightning activity. Earth's top-ranked lightning hotspot occurs over Lake Maracaibo in Venezuela where lightning occurs 297 days per year (with a peak in September) due to convergent land breeze over this hot lake. Lake Victoria (as well as other lakes along the East African Rift Valley) exhibits deep nocturnal convective activity driven by locally forced land breezes. The second-ranked lightning hotspot on Earth is at Kahuzi-Biéga National Park, near the city of Kabare in Democratic Republic of the Congo on the west side of the Mitumba Mountains. Several African lightning maxima are located along this mountain range, with strong afternoon lightning activity all year long with peaks in March and September. Asia's lightning hotspot is at the northwestern ridges of the Himalayas, near Daggar, Pakistan. Its annual and diurnal cycles show maximum activity, respectively, in the summer and late afternoon to early evening. North America and Oceania's top lightning hotspots are, respectively, in Patulul, Guatemala, and Derby, Australia, with afternoon and summer maximums. In the United States, the lightning hotspot is in the Everglades, near Orangetree, Florida, which is ranked in 14th position in North America and 122nd globally.

Court and Griffiths (1982) found that the place in the world with more thunderstorms per day was in Uganda (242), followed by the Democratic Republic of the Congo (formerly Zaire; 228) and Rwanda (221). These last two locations are within $200 \mathrm{~km}$ from Kabare, Democratic Republic of the Congo, the second hotspot of Earth found in the current study. Unfortunately, they did not have data from Venezuela. Court and Griffiths (1982, p. 33) also observed that most thunderstorm days were associated with complex terrain and coastal lines and stated, "There is a relation, although not perfect, with topography, land-sea configuration, airmass movements and airflow on all scales." In fact, from the first 30 lightning hotspots only 6 are not near mountainous regions. For example, the strongest 
hotspots from each continental landmass are near or related to mountainous regions: Lake Maracaibo in South America, Kabare in Africa, Daggar (Pakistan) in Asia, and Patulul (Guatemala) in North America, with the exception being that Oceania's top hotspot occurs in Derby (Australia) within a flat coast region. These features are so localized that they are only recognized when looking at the fine scales of the interaction between the wind and complex terrain that leads to cloud development. Nesbitt and Anders (2009) and Biasutti et al. (2012) explored TRMM Precipitation Radar climatologies at very high resolutions $\left(0.1^{\circ}\right.$ and $0.05^{\circ}$, respectively) to investigate the role of topography and coastlines affecting tropical rainfall distributions. Nesbitt and Anders (2009) found high precipitation accumulations over narrow bands from 500 to 2,000 $\mathrm{m}$ in elevation at the eastward foothills of the Andes as well as a distinctly drier region along high $(>2,000 \mathrm{~m})$ slopes of the northern portion and Altiplano to the south. Here, lightning activity in very high terrain is also very low $\left(<2 \mathrm{fl} \mathrm{km}^{-2} \mathrm{yr}^{-1}\right)$ or absent, distinctly marking the Andes mountain ranges along the South American west coast, the Sierra Madre in Mexico, and the Himalayas in Asia. One noticeable exception is the northern range over Colombia and Venezuela. Whereas most of the accumulated precipitation is found west of the Andes toward the ocean (Mapes et al. 2003b; Nesbitt and Anders 2009; Biasutti et al. 2012), lightning activity is concentrated within the several valleys between the mountain ranges, marking two distinct regimes of rain yield per flash: high precipitation rates and moderate lightning activity toward the ocean (high rain yield per flash) and high precipitation rates and high FRD along the valleys (low rain yield per flash; Takayabu 2006).

After over 17 years of operational service, the TRMM mission came to a close as the satellite used up its fuel and began a slow orbital descent that began in October 2014 and ended when the LIS instrument was powered off on 8 April 2015 when TRMM reached its decommissioning altitude of $335 \mathrm{~km}$. This and all previous work related to TRMM LIS and OTD have proven the excellent low-Earth-orbit lightning measurements. To extend the continuity of these measurements, a space-qualified LIS, built as the flight spare for TRMM, will be launched on a science mission to the International Space Station (ISS) in an orbit altitude $(426 \mathrm{~km})$ similar to TRMM LIS (402 km) (Blakeslee and Koshak 2016). This LIS is expected to be launched and placed in operation aboard the ISS in early-to mid2017 (R. Blakeslee 2016, personal communication). Moreover, in November 2016 the next generation of
NOAA geostationary satellites, the GOES-R series, will be launched with the first Geostationary Lightning Mapper (GLM) that will provide unprecedented continuous day and night total lightning observations from geostationary orbit and extend the climate dataset begun with OTD and TRMM LIS for another 20-30 years. Therefore, the present study provides insight and context to forecasters and researchers who will use total lightning activity to better understand the earth around us.

ACKNOWLEDGMENTS. We would like to acknowledge the support of the NASA Earth Science Division and the NOAA GOES-R Science Office in addition to the work of all LIS Science Team members. All past and current members have contributed in some degree to the success of this mission. A special thanks is offered to Dennis Boccippio, who developed the source code for OTD and LIS gridded climatologies, which were modified here to obtain the very high-resolution grid $\left(0.1^{\circ}\right)$ results. We also thank the editor, Edward Zipser, and three anonymous reviewers for their helpful comments and suggestions. Douglas Mach (USRA), thank you for the discussions on LIS algorithm and flash length. LIS data used in this work and the gridded climatologies produced here are distributed by the NASA EOSDIS Global Hydrology Resource Center Data Analysis and Archive Center (DAAC), Huntsville, Alabama, (http:// thunder.nsstc.nasa.gov). The views, opinions, and findings contained in this report are those of the authors.

\section{REFERENCES}

Albrecht, R. I., S. J. Goodman, W. A. Petersen, D. E. Buechler, E. C. Bruning, R. J. Blakeslee, and H. J. Christian, 2011a: The 13 years of TRMM Lightning Imaging Sensor: From individual flash characteristics to decadal tendencies. Extended Abstracts, 14th Int. Conf. on Atmospheric Electricity, Rio de Janeiro, Brazil, ICAE, 1-4. [Available online at http://ntrs.nasa .gov/archive/nasa/casi.ntrs.nasa.gov/20110015779 .pdf.]

—, C. A. Morales, and M. A. F. Silva Dias, 2011b: Electrification of precipitating systems over the Amazon: Physical processes of thunderstorm development. J. Geophys. Res., 116, D08209, doi:10.1029/2010JD014756.

— D. J. Cecil, and S. J. Goodman, 2014: Lightning. Encyclopedia of Remote Sensing, E. G. Njoku, Ed., Encyclopedia of Earth Sciences Series, Springer, 339-344.

Amador, J. A., 1998: A climatic feature of the tropical Americas: The trade wind easterly jet. Top. Meteor. Oceanogr., 5, 91-102. 
_ 2008: The intra-Americas sea low-level jet: Overview and future research. Ann. N. Y. Acad. Sci., 1146, 153-188, doi:10.1196/annals.1446.012.

Ba, M. B., and S. E. Nicholson, 1998: Analysis of convective activity and its relationship to the rainfall over the Rift Valley Lakes of East Africa during 1983-90 using the Meteosat infrared channel. J. Appl. Meteor., 37, 1250-1264, doi:10.1175/1520-0450(1998)037 $<1250$ :AOCAAI $>2.0 . C O ; 2$.

Balas, N., S. E. Nicholson, and D. Klotter, 2007: The relationship of rainfall variability in west central Africa to sea-surface temperature fluctuations. Int. J. Climatol., 27, 1335-1349, doi:10.1002/joc.1456.

Barros, A. P., and T. J. Lang, 2003: Monitoring the monsoon in the Himalayas: Observations in central Nepal, June 2001. Mon. Wea. Rev., 131, 1408-1427, doi:10.1175/1520-0493(2003)131<1408:MTMITH $>2.0 . \mathrm{CO} ; 2$.

—, G. Kim, E. Williams, and S. W. Nesbitt, 2004: Probing orographic controls in the Himalayas during the monsoon using satellite imagery. Nat. Hazards Earth Syst. Sci., 4, 29-51, doi:10.5194/nhess -4-29-2004.

Biasutti, M., S. E. Yuter, C. D. Burleyson, and A. H. Sobel, 2012: Very high resolution rainfall patterns measured by TRMM precipitation radar: Seasonal and diurnal cycles. Climate Dyn., 39, 239-258, doi:10.1007 /s00382-011-1146-6.

Blakeslee, R, and W. Koshak, 2016: LIS on ISS: Expanded global coverage and enhanced applications, Earth Obs., 28, 4-14. [Available online at http://eospso.nasa .gov/sites/default/files/eo_pdfs/May_June_2016 _color\%20508.pdf.]

Boccippio, D. J., S. J. Goodman, and S. J. Heckman, 2000: Regional differences in tropical lightning distributions. J. Appl. Meteor., 39, 2231-2248, doi:10.1175/1520-0450(2001)040<2231:RDITLD $>2.0 . \mathrm{CO} ; 2$.

Brooks, C. E. P., 1925: The distribution of thunderstorms over the globe. Geophys. Mem., 24, 147-164.

Buechler, D. E., W. J. Koshak, H. J. Christian, and S. J. Goodman, 2014: Assessing the performance of the Lightning Imaging Sensor (LIS) using deep convective clouds. Atmos. Res., 135-136, 397-403, doi:10.1016/j.atmosres.2012.09.008.

Bürgesser, R. E., M. G. Nicora, and E. E. Ávila, 2012: Characterization of the lightning activity of "Relámpago del Catatumbo." J. Atmos. Sol. Terr. Phys., 77, 241-247, doi:10.1016/j.jastp.2012.01.013.

Cecil, D. J., and C. B. Blankenship, 2012: Toward a global climatology of severe hailstorms as estimated by satellite passive microwave imagers. J. Climate, 25, 687-703, doi:10.1175/JCLI-D-11-00130.1.
- S. J. Goodman, D. J. Boccippio, E. J. Zipser, and S. W. Nesbitt, 2005: Three years of TRMM precipitation features. Part I: Radar, radiometric, and lightning characteristics. Mon. Wea. Rev., 133, 543-566, doi:10.1175 /MWR-2876.1.

— D. E. Buechler, and R. J. Blakeslee, 2014: Gridded lightning climatology from TRMM-LIS and OTD: Dataset description. Atmos. Res., 135-136, 404-414, doi:10.1016/j.atmosres.2012.06.028.

Christian, H. J., R. J. Blakeslee, and S. J. Goodman, 1992: Lightning Imaging Sensor (LIS) for the Earth Observing System. NASA Tech. Memo. 4350, 36 pp. — tribution of lightning as observed from space by the Optical Transient Detector. J. Geophys. Res., 108, 4005, doi:10.1029/2002JD002347.

Codazzi, A., 1841: Resuimen de la Geografiia de Venezuela. Impr. de H. Fournier y compia, 648 pp.

Court, A., and J. F. Griffiths, 1982: Thunderstorm climatology. Thunderstorm Morphology and Dynamics of Thunderstorms: A Social, Scientific, and Technological Documentary, E. Kessler, Ed., University of Oklahoma Press, 11-52.

Falcon, N., 2011: Phenomenology and microphysics of lightning flash of the Catatumbo River (Venezuela). Proc. 14th Int. Conf. on Atmospheric Electricity, Rio de Janeiro, Brazil, ICAE, 1-4.

Flohn, H., and K. Fraedrich, 1966: Tagesperiodische zirkulation und niederschlagsverteilung am VictoriaSee (Ostafrika) [The daily periodic circulation and distribution of rainfall over Lake Victoria (East Africa)]. Meteor. Rundsch., 19, 157-165.

Futyan, J. M., and A. D. Del Genio, 2007: Relationships between lightning and properties of convective cloud clusters. Geophys. Res. Lett., 34, L15705, doi:10.1029/2007GL030227.

Garreaud, R., and J. M. Wallace, 1997: The diurnal march of convective cloudiness over the Americas. Mon. Wea. Rev., 125, 3157-3171, doi:10.1175/15200493(1997)125<3157:TDMOCC>2.0.CO;2.

Goodman, S. J., and H. J. Christian, 1993: Global observations of lightning. Atlas of Satellite Observations Related to Global Change, R. J. Gurney, J. L. Foster, and C. L. Parkinson, Eds., Cambridge University Press, 191-219.

—, D. E. Buechler, K. Knupp, K. Driscoll, and E. W. McCaul Jr., 2000: The 1997-98 El Nino event and related wintertime lightning variations in the southeastern United States. Geophys. Res. Lett., 27, 541-544, doi:10.1029/1999GL010808.

—_ — - and E. W. McCaul Jr., 2007: Lightning. Our Changing Planet: The View from Space, M. King et al., Eds., Cambridge University Press, 44-52. 
Heckman, S. J., E. Williams, and B. Boldi, 1998: Total global lightning inferred from Schumann resonance measurements. J. Geophys. Res., 103, 31 775-31779, doi:10.1029/98JD02648.

Houze, R. A., D. C. Wilton, and B. F. Smull, 2007: Monsoon convection in the Himalayan region as seen by the TRMM Precipitation Radar. Quart. J. Roy. Meteor. Soc., 133, 1389-1411, doi:10.1002/qj.106.

Jackson, B., S. E. Nicholson, and D. Klotter, 2009: Mesoscale convective systems over western equatorial Africa and their relationship to large-scale circulation. Mon. Wea. Rev., 137, 1272-1294, doi:10.1175/2008MWR2525.1.

Jayaratne, E. R., and Y. Kuleshov, 2006: Geographical and seasonal characteristics of the relationship between lightning ground flash density and rainfall within the continent of Australia. Atmos. Res., 79, 1-14, doi:10.1016/j.atmosres.2005.03.004.

Kandalgaonkar, S. S., 2003: Diurnal variation of lightning activity over the Indian region. Geophys. Res. Lett., 30, 2022, doi:10.1029/2003GL018005.

_-, 2005: Spatio-temporal variability of lightning activity over the Indian region. J. Geophys. Res., 110, D11108, doi:10.1029/2004JD005631.

Kodama, Y.-M., A. Ohta, M. Katsumata, S. Mori, S. Satoh, and H. Ueda, 2005: Seasonal transition of predominant precipitation type and lightning activity over tropical monsoon areas derived from TRMM observations. Geophys. Res. Lett., 32, L14710, doi:10.1029/2005GL022986.

Kotaki, M., 1984: Global distribution of atmospheric radio noise derived from thunderstorm activity. $J$. Atmos. Terr. Phys., 46, 867-877, doi:10.1016/0021 -9169(84)90026-6.

Kuleshov, Y., D. Mackerras, and M. Darveniza, 2006: Spatial distribution and frequency of lightning activity and lightning flash density maps for Australia. J. Geophys. Res., 111, D19105, doi:10.1029 /2005JD006982.

Laing, A. G., and J. M. Fritsch, 1993: Mesoscale convective complexes in Africa. Mon. Wea. Rev., 121, 22542263, doi:10.1175/1520-0493(1993)121<2254:MCCIA $>2.0 . \mathrm{CO} ; 2$.

—, and J. M. Fritsch, 1997: The global population of mesoscale convective complexes. Quart. J. Roy. Meteor. Soc., 123, 389-405, doi:10.1002/qj .49712353807 .

Lal, D. M., and S. D. Pawar, 2009: Relationship between rainfall and lightning over central Indian region in monsoon and premonsoon seasons. Atmos. Res., 92, 402-410, doi:10.1016/j.atmosres.2008.12.009.

Liu, C., D. Cecil, and E. J. Zipser, 2011: Relationships between lightning flash rates and passive microwave brightness temperatures at 85 and $37 \mathrm{GHz}$ over the tropics and subtropics. J. Geophys. Res., 116, D23108, doi:10.1029/2011JD016463.

Lott, J. N., R. Vose, S. A. Del Greco, T. F. Ross, S. Worley, and J. L. Comeaux, 2008: The integrated surface database: Partnerships and progress. Proc. 24th Conf. on IIPS, New Orleans, LA, Amer. Meteor. Soc., 3B.5. [Available online at https://ams.confex.com /ams/88Annual/techprogram/paper_131387.htm.]

Mackerras, D., M. Darveniza, R. E. Orville, E. R. Williams, and S. J. Goodman, 1998: Global lightning: Total, cloud and ground flash estimates. J. Geophys. Res., 103, 19791-19809, doi:10.1029/98JD01461.

Mapes, B. E., T. T. Warner, and M. Xu, 2003a: Diurnal patterns of rainfall in northwestern South America. Part III: Diurnal gravity waves and nocturnal convection offshore. Mon. Wea. Rev., 131, 830-844, doi:10.1175/1520-0493(2003)131<0830:DPORIN $>2.0 . \mathrm{CO} ; 2$.

— , T. T. Warner, M. Xu, and A. J. Negri, 2003b: Diurnal patterns of rainfall in northwestern South America. Part I: Observations and context. Mon. Wea. Rev., 131, 799-812, doi:10.1175/1520-0493(2003)131 $<0799$ :DPORIN $>2.0 . C O ; 2$.

Martinez, M., J. Ramirez, and R. Montano, 2003: Actividad de rayos en Venezuela, utilizando la data del sensor óptico (LIS) del proyecto TRMM de la NASA. Rev. Téc. Fac. Ing., Univ. Zulia, 26, 127-139.

Muñoz, E., A. J. Busalacchi, S. Nigam, and A. RuizBarradas, 2008: Winter and summer structure of the Caribbean low-level jet. J. Climate, 21, 1260-1276, doi:10.1175/2007JCLI1855.1.

Muñoz, Á. G., J. Daz-Lobatón, X. Chourio, and M. J. Stock, 2016: Seasonal prediction of lightning activity in north western Venezuela: Large-scale versus local drivers. Atmos. Res., 172-173, 147-162, doi:10.1016/j .atmosres.2015.12.018.

Negri, A. J., E. N. Anagnostou, and R. F. Adler, 2000: A 10-yr climatology of Amazonian rainfall derived from passive microwave satellite observations. J. Appl. Meteor., 39, 42-56, doi:10.1175/1520 -0450(2000)039<0042:AYCOAR>2.0.CO;2.

Nesbitt, S. W., and E. J. Zipser, 2003: The diurnal cycle of rainfall and convective intensity according to three years of TRMM measurements. J. Climate, 16, 1456-1475, doi:10.1175/1520-0442-16.10.1456.

—, and A. M. Anders, 2009: Very high resolution precipitation climatologies from the Tropical Rainfall Measuring Mission precipitation radar. Geophys. Res. Lett., 36, L15815, doi:10.1029/2009GL038026.

Nicholson, S. E., 1996: A review of climate dynamics and climate variability in eastern Africa. Limnology, Climatology and Paleoclimatology of the East African 
Lakes, T. C. Johnson and E. O. Odada, Eds., CRC Press, 25-56.

— , 2009: A revised picture of the structure of the "monsoon" and land ITCZ over West Africa. Climate Dyn., 32, 1155-1171, doi:10.1007/s00382-0080514-3.

- , and X. Yin, 2002: Mesoscale patterns of rainfall, cloudiness and evaporation over the Great Lakes of East Africa. The East African Great Lakes: Limnology, Palaeolimnology and Biodiversity, E. O. Odada and D. O. Olago, Eds., Advances in Global Change Research Series, Vol. 12, Springer, 93-119.

— , and J. P. Grist, 2003: The seasonal evolution of the atmospheric circulation over West Africa and equatorial Africa. J. Climate, 16, 1013-1030, doi:10.1175/1520-0442(2003)016<1013:TSEOTA $>2.0 . \mathrm{CO} ; 2$.

Orville, R. E., and R. W. Henderson, 1986: Global distribution of midnight lightning: September 1977 to August 1978. Mon. Wea. Rev., 114, 2640-2653, doi:10.1175/1520-0493(1986)114<2640:GDOMLS $>2.0 . \mathrm{CO} ; 2$.

Petersen, W. A., H. J. Christian, and S. A. Rutledge, 2005: TRMM observations of the global relationship between ice water content and lightning. Geophys. Res. Lett., 32, L14819, doi:10.1029/2005GL023236.

—, R. Fu, M. Chen, and R. Blakeslee, 2006: Intraseasonal forcing of convection and lightning activity in the southern Amazon as a function of cross-equatorial flow. J. Climate, 19, 3180-3196, doi:10.1175/JCLI3788.1.

Poveda, G., and Coauthors, 2005: The diurnal cycle of precipitation in the tropical Andes of Colombia. Mon. Wea. Rev., 133, 228-240, doi:10.1175/MWR -2853.1 .

Pulwarty, R. S., R. G. Barry, C. M. Hurst, K. Sellinger, and L. F. Mogollon, 1998: Precipitation in the Venezuelan Andes in the context of regional climate. Meteor. Atmos. Phys., 67, 217-237, doi:10.1007/BF01277512.

Rasmussen, K. L., and R. A. Houze, 2011: Orogenic convection in subtropical South America as seen by the TRMM satellite. Mon. Wea. Rev., 139, 2399-2420, doi:10.1175/MWR-D-10-05006.1.

— , M. D. Zuluaga, and R. A. Houze, 2014: Severe convection and lightning in subtropical South America. Geophys. Res. Lett., 41, 7359-7366, doi:10.1002 /2014GL061767.
Takayabu, Y. N., 2006: Rain-yield per flash calculated from TRMM PR and LIS data and its relationship to the contribution of tall convective rain. Geophys. Res. Lett., 33, L18705, doi:10.1029/2006GL027531.

Vera, C., and Coauthors, 2006: The South American Low-Level Jet Experiment. Bull. Amer. Meteor. Soc., 87, 63-77, doi: 10.1175/BAMS-87-1-63.

Virts, K. S., J. M. Wallace, M. L. Hutchins, and R. H. Holzworth, 2013: Highlights of a new ground-based, hourly global lightning climatology. Bull. Amer. Meteor. Soc., 94, 1381-1391, doi:10.1175/BAMS-D-12-00082.1.

Wang, C., 2007: Variability of the Caribbean low-level jet and its relations to climate. Climate Dyn., 29, 411-422, doi:10.1007/s00382-007-0243-z.

Williams, E., 2004: Islands as miniature continents: Another look at the land-ocean lightning contrast. J. Geophys. Res., 109, D16206, doi:10.1029 /2003JD003833.

— tion of cloud electrification and the global diurnal variation of negative charge on the earth. J. Geophys. Res., 98, 5221, doi:10.1029/92JD02642.

—, and S. Stanfill, 2002: The physical origin of the land-ocean contrast in lightning activity. C. R. Phys., 3, 1277-1292, doi:10.1016/S1631-0705(02)01407-X.

—, K. Rothkin, D. Stevenson, and D. Boccippio, 2000: Global lightning variations caused by changes in thunderstorm flash rate and by changes in the number of thunderstorms. J. Appl. Meteor., 39, 2223-2230, doi:10.1175/1520-0450(2001)040<2223:GLVCBC $>2.0 . \mathrm{CO} ; 2$.

— , and Coauthors, 2002: Contrasting convective regimes over the Amazon: Implications for cloud electrification. J. Geophys. Res., 107, 8082, doi:10.1029/2001JD000380.

WMO, 1953: World Distribution of thunderstorm days. Part I: Tables. WMO Publication 21, TP 6, xxx pp.

Yin, X., S. E. Nicholson, and M. B. Ba, 2000: On the diurnal cycle of cloudiness over Lake Victoria and its influence on evaporation from the lake. Hydrol. Sci. J., 45, 407-424, doi:10.1080/02626660009492338.

Zipser, E. J., C. Liu, D. J. Cecil, S. W. Nesbitt, and D. P. Yorty, 2006: Where are the most intense thunderstorms on Earth? Bull. Amer. Meteor. Soc., 87, 1057-1071, doi:10.1175/BAMS-87-8-1057. 